University for Business and Technology in Kosovo

UBT Knowledge Center

UBT International Conference

2016 UBT International Conference

Oct 28th, 9:00 AM - Oct 30th, 5:00 PM

\title{
Can a new railway track be used to foster smart urban and regional development?
}

Thomas Dillinger

Vienna University of Technology, thomas.dillinger@tuwien.ac.at

Markus Neuhaus

Vienna University of Technology, markus.neuhaus@tuwien.ac.at

Follow this and additional works at: https://knowledgecenter.ubt-uni.net/conference

Part of the Architecture Commons

\section{Recommended Citation}

Dillinger, Thomas and Neuhaus, Markus, "Can a new railway track be used to foster smart urban and regional development?" (2016). UBT International Conference. 62.

https://knowledgecenter.ubt-uni.net/conference/2016/all-events/62

This Event is brought to you for free and open access by the Publication and Journals at UBT Knowledge Center. It has been accepted for inclusion in UBT International Conference by an authorized administrator of UBT Knowledge Center. For more information, please contact knowledge.center@ubt-uni.net. 
Can a new railway track be used to foster smart urban and regional development?

\title{
Can a new railway track be used to foster smart urban and regional development?
}

\author{
Thomas Dillinger, Markus Neuhaus \\ Vienna University of Technology, Department of Spatial Planning, Center for Regional \\ Planning and Regional Development, Operngasse $11 / 5^{\text {th }}$ floor, 1040 Wien \\ \{thomas.dillinger, markus.neuhaus\}@ tuwien.ac.at
}

\begin{abstract}
The future Smart City Ebreichsdorf (SMCE) is a fast growing municipality in the area of the metropolitan region of Vienna, Lower Austria and Burgenland. The expansion to a double track railroad of the „Pottendorfer Linie“and the thereby even better connexion to Ebreichsdorf will strengthen this growing process even more. A new train station is built, located on a greenfield site, between the city districts Ebreichsdorf and Unterwaltersdorf. The existing railway track is going to be abandoned. In spatial planning approaches, it's goal leading to locate future growth in the area of the new train station. Action options, how such an innovative growth process around the railway station could be formed, are absent up to now. The state Lower Austria and the city Ebreichsdorf are aware of this problem. So the idea of planning and implementing a „Smart City“ or a „Smart Urban Region“ at this certain area has moved in focus of considerations. An urban transformation towards a future smart city is necessary. The Smart City concept gets more and more important in the course of urban and regional development. Thereby, new technologies are used to create a sustainable environment and economy in order to ensure the quality of life for the further generations. The participation and awareness of the citizens are of fundamental importance. With a focus on Ebreichsdorf this paper demonstrates how such an impulse can be used for a smart urban and regional development. First results of the ongoing project show, that it is advantageous to involve citizens and main stakeholders as well as all political parties in an early stage. This increases the acceptance and facilitates the further process. Furthermore, the complexity of Smart City is best handled by a team of researchers from various disciplines. In the course of a scenario workshop, it became clear that all different disciplines have different accesses to the same topic. Through this a stimulating discussion and exchange of experiences has been started.
\end{abstract}

Keywords: Smart City, Smart Region, Urban and Regional Development, Railway Infrastructure

\section{Spatial Challenge}

The project Smart City Ebreichsdorf (SMCE) is a research project concentrating on energy efficient and sustainable development of the municipality Ebreichsdorf with due regard to surrounding municipalities. The future Smart City Ebreichsdorf is a fast growing city in the area of the metropolitan region of Vienna, Lower Austria and Burgenland. The southern suburbs of Vienna such as the region 
Book of Proceedings

International Conference on Architecture and Spatial Planning

surrounding Ebreichsdorf are gaining from the growth of the Austrian Capital City Vienna. Furthermore the Austrian Federal Railways (ÖBB) is currently expanding the southern route from the new Vienna central station "Wien Hauptbahnhof" across the newly build freight center "Güterzentrum Wien Süd (Inzersdorf)", the "Pottendorfer Linie" up to a new 27,3 km long tunnel "Semmering Basistunel" between Lower Austria and Styria (see Fig. 1). Especially the new freight center in Inzersdorf as well as the growing suburban region in the south of Vienna and the faster connection to Styria making the expansion of the southern route into a four track railroad between Wiener Neustadt and Vienna necessary (ÖBB Infra, n.d.).

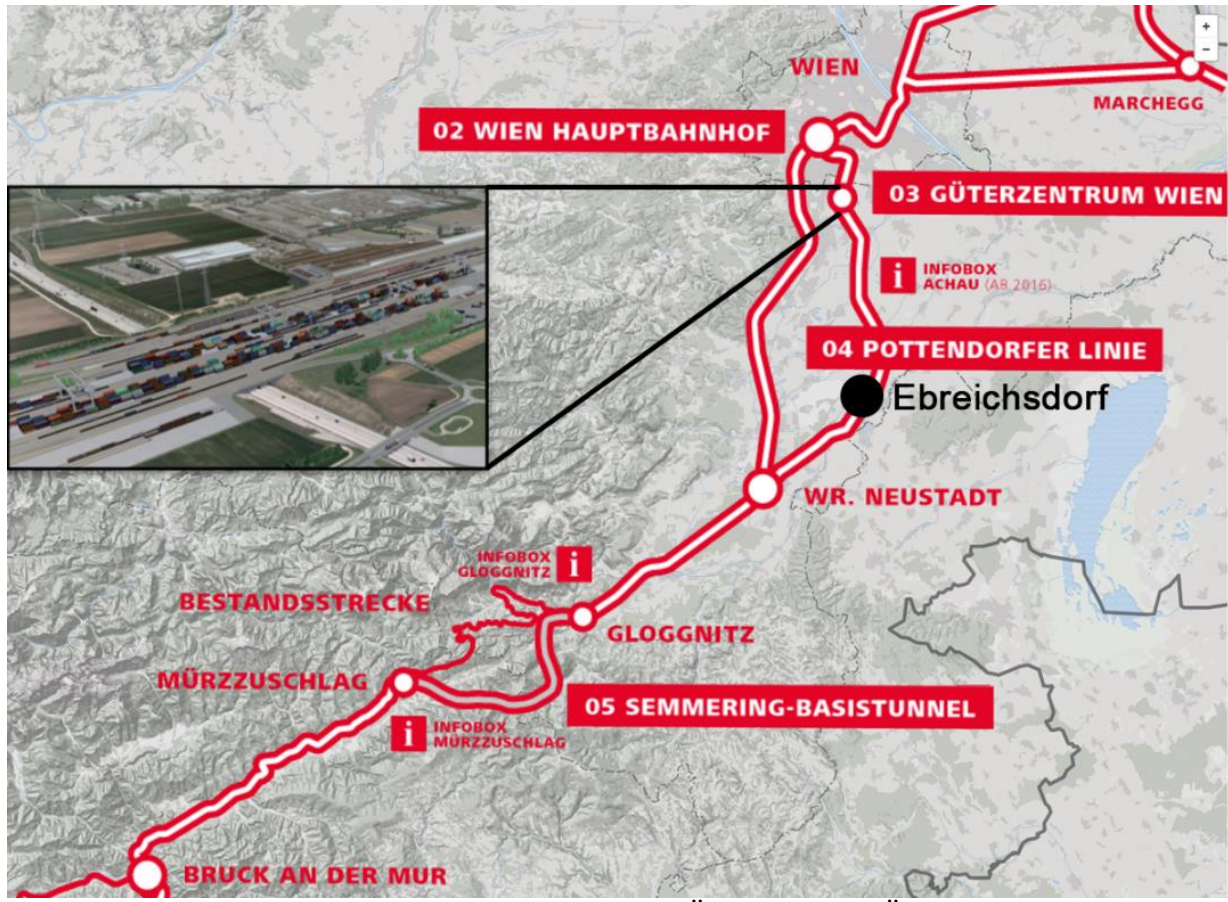

Fig. 1: The new southern route "Südstrecke" of the ÖBB (Source: (ÖBB Infra, 2016 b); own presentation)

A new impulse for the region will be the expansion of the "Pottendorfer Linie" to a double track railroad. This will reduce the traveling time from Ebreichsdorf to Vienna to less than 25 minutes and strengthen the growth process of the city and the region even more than now. As part of the expansion a new railway station is going to be built on the "green field" between the two city districts Ebreichsdorf and Unterwaltersdorf within a distance of about 500 meters to each urban center (OBB Infra, 2016 a). The existing railway is going to be abandoned (see Fig. 2), while the new railroad as well as the new train station should provide their full services in 2023.

This current development of Ebreichsdorf results in new challenges like the development of the existing and new train station as well as expected growth processes. The state Lower Austria and the City Ebreichsdorf are well aware of the future challenges. Thus the idea of planning and implementing a 
„Smart City“ or a „Smart Urban Region“ at this certain area has moved in focus of considerations. According to spatial planning approaches, it is goal leading to locate zones of future growth in the area of new railway stations. Possible options of action to form such an innovative growth process around the railway station are absent up to now. As well as forming the growth process the future use of the existing railway line should be discussed at an early stage. This research project, aims to answer the question, how this new railroad track and station can be used as an impulse for smart urban and regional development. The main aim is to initiate a process of awareness building and reflection. Hence, the focus in the first step is not on concrete solutions, but on the examination of potential actions and planning processes.

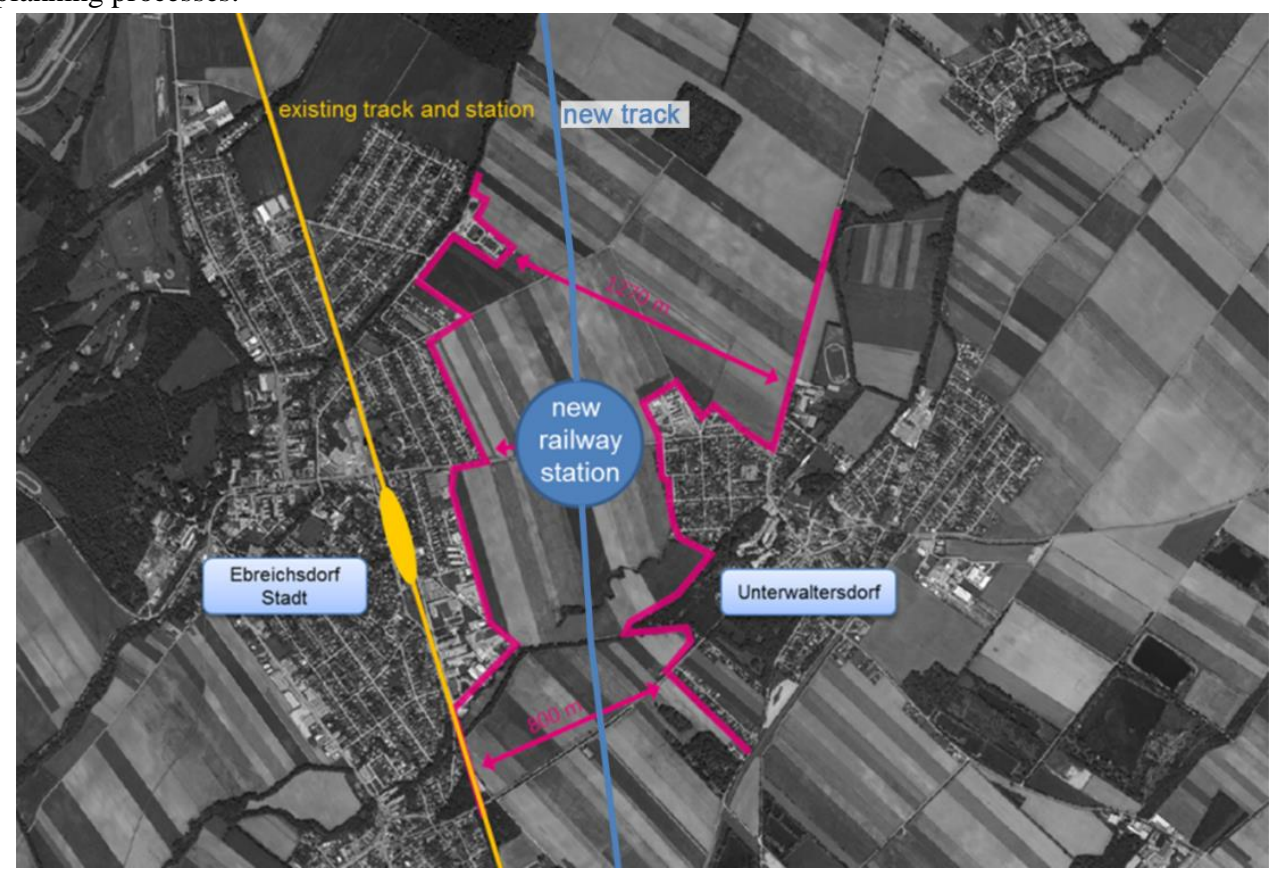

Fig. 2: Location of the new railway station Ebreichsdorf (Source: map data (google maps, 2016), own presentation)

\section{The "Smart City" concept in theory}

The term "Smart City" has come to be well known by a wide section of the population and often used by municipalities as well as in politics, although there is no shared definition about the concept of a "Smart City". Even in recent years there have been different projects concerning this term (Dameri, 2013) (Hollands, 2008). This urban labeling has often been associated with new technical-based solutions to counteract the challenges of growing cities and urbanization along with several technical, economic or social problems.

An aim of Smart City is to create a sustainable environment and economy in order to ensure the quality of life for the further generations. The city performance should primarily be improved by using 


\section{Book of Proceedings \\ International Conference on Architecture and Spatial Planning}

Information and Communication Technologies (ICT) (Neirotti, et al., 2014). However, the term "Smart" is not only used as positive description for urban-technological innovations and adjustments like ICTs, but also as a synonym for cities with special focus for e-governance, participation, communities and social learning in order to gain more public and social value (Hollands, 2008). In contrary to that, citizens are often ignored in the definition of Smart City, although they can be seen as a fundamental aspect of the concept (Dameri, 2013). As Caragliu et al. (2011) has shown social and human capital such as social skills are essential ingredients for smart city performances. Thus, considering only "hard" infrastructure as well as the exclusive focus on ICTs and technological improvements are not expedient. This means, that "smart" depicts a combination of technological and socioeconomic development (Nam \& Pardo, 2011 b).

Due to the many possibilities to define Smart City, there are also different ways to describe the specific characteristics. Giffinger \& Heindlmayer (2010) identify six smart capacities such as environment, mobility, people, governance, economy and living, which rely on independency and awareness of citizens. To specify each characteristic several factors are mentioned. For example, smart environment is defined as sustainable resource management and environmental protection in order to ease pollution. Linked to this topic smart mobility is defined by sustainable, innovative and safe transport systems as well as the local accessibility to transportation systems amongst others. Together these characteristics can make a major contribution to save energy and to use green energy. In order to implement a forwardlooking development of the built environment smart living, as housing quality or social infrastructure, and smart economy in terms of competitiveness are primarily mentioned. Lastly flexibility, creativity, open-mindedness and participation in public life are examples for smart people. Possibilities of participation, transparent governance as well as social and public services can be mentioned as aspects for smart governance. Comparing these two characteristics, smart people and smart governance, highlights, that there's quite an overlap between them.

Due to a lack of only one valid definition of Smart City, also other characteristics like smart transportation, smart education or smart energy can be mentioned (Nam \& Pardo, 2011 a), but they all have similar intentions by using ICTs and awareness of citizens to preserve or even improve the quality of live as well as to protect the environment through resource-saving technologies.

\section{From theory to practice ${ }^{43}$}

Once the final route of the "Pottendorfer Linie" has been decided in 2014, the first contact between the Municipality Ebreichsdorf and the Technical University of Vienna took place. The size and complexity of the planning project exceeds the capacities of the municipality of Ebreichsdorf, comparable to similar areas in other big cities. Moreover, justified concerns and unreflective reservations about new developments exist within the population of Ebreichsdorf. The region is lacking visions, mission statements as well as quality standards for processes, planning and implementation for development projects of this dimension. Moreover, the medium- and long-term regional impacts of the development of Ebreichsdorf go far beyond limits of the city. Thus, it is not only a local, but also a regional planning task, which requires intensive coordination with the state of Lower Austria and regional stakeholders. Now is the time to create a clear vision of the future development of Ebreichsdorf, otherwise fragmented and disordered development has to be expected.

${ }^{43}$ cp.: TU Wien, Stadtgemeinde Ebreichsdorf, Energiepark Bruck/Leitha, Energie- und Umweltagentur NÖ, 2015. Projektantrag Smart City Ebreichsdorf (SMCE). Wien: TU Wien 
Can a new railway track be used to foster smart urban and regional development?

The Province of Lower Austria and the City Ebreichsdorf are aware of the dimensions of this planning task. Therefore, this project was preceded by a preliminary study and excursion to municipalities in Vorarlberg, the agglomerations Zurich and Munich with similar challenges on behalf of the Lower Austrian Government. Within the scope of the excursion representatives of Lower Austria, the Municipality of Ebreichsdorf and other Municipalities in Lower Austria, which find themselves in similar situations, have participated. In the course of the excursion the City Ebreichsdorf, the Province of Lower Austria as well as regional actors have recognized the need for new prospects. Therefore, the developments at this location can be connected with the Smart City programmatic. Especially the integrative and system-optimizing approach of "Smart City" is highly suitable for the development of such districts.

In February 2016 the SMCE-project started as an exploratory study funded by the Austrian Research Promotion Agency (FFG) with a maturity of one year. There are two different modes to get a financial support, on one hand as an exploratory study with a project term of maximum one year and $200.000 €$ foundation (so called "Sondierungsprojekt"), on the other hand as a "Demoprojekt" with a term of 2 4 years and up to 5 Mio $€$ financial support (FFG, 2015). Ebreichsdorf and Lower Austria consider this project as preparation for subsequent implementations in the city district as a "test bed". Conducting an exploratory study the necessary dimensions of action can be developed, criteria for an innovative implementation can be defined and necessary actors for the later demonstration project can be involved at an early stage. It is also possible to confront and familiarize a wider public of the region with the "Smart City" concept, to thereby start the necessary social innovation process. The innovation value of the present project compared with the state of the technology exists in the early linking of the following three components of the exploratory study.

a.) Temporal rhythm of process: The new railroad as well as the new train station should provide their full services in 2023. It is now the proper time to make the "imaginable" and the "possible" subjects of discussion and further to start a dialogue in politics, administration, public and science.

b.) Political / administrative positioning: The federal state Lower Austria, the regional stakeholders (such as Regionalmanagement Wien Umland Süd, NÖ Energie und Umweltagentur, Stadt- und Dorferneuerung) as well as the city of Ebreichsdorf are already integrated actively in this project. Added to that support of the ÖBB is given. This early integration of actors is prerequisite for a safe implementation of the expected scientific results in future times.

c.) Interdisciplinary: The research team consists of scientists specialised in many different fields, such as regional planning, architecture, urban planning, landscape planning, mobility planning, social sciences as well as energy and resource planning. This variety makes an interdisciplinary thinking and work possible and ensures an integrated complete solution.

Within the scope of SMCE four characteristics have been defined to describe sustainable development of the city and region Ebreichsdorf. These characteristics are smart governance, smart mobility, smart development and smart energy. All defined qualities represent the four major work packages of the research project, except work package five "PR, dissemination and project management". Smart development, smart mobility and smart energy depict three thematic priorities, which are embedded in general considerations of planning and implementing Smart City Ebreichsdorf. Thus, the necessary resource requirements are going to be estimated starting from the new train station, to the surrounding district up to the whole region. As discussed before, literature suggests different characteristics concerning smart cities. Main topics are participation, responsible energy use and sustainable transport systems as well as consideration of cultural and social facilities within the development of the built environment to reach high quality of life. These topics are reflected in the defined characteristics of SMCE, as smart governance considers participation of different social groups as well as land policies. 
Book of Proceedings

International Conference on Architecture and Spatial Planning

Smart mobility concentrates on urban areas, intermodality and a multifunctional railway station. Further, smart development regards sustainable building as well as mixed use while smart energy focuses on energy-efficient settlement structures and infrastructures as well as creating awareness. Following the four major work packages are being described in detail (see Fig. 3).

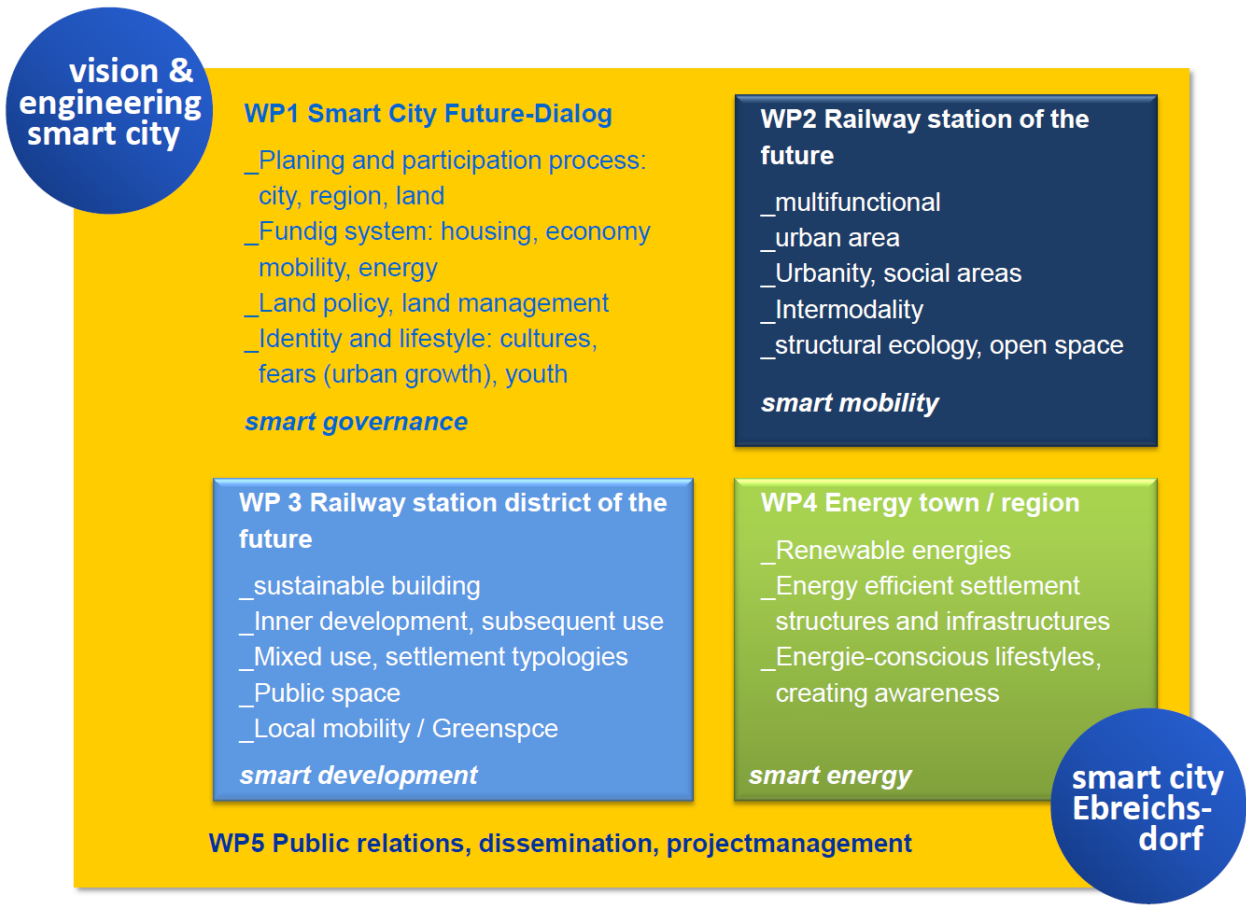

Fig. 3: Work packages of SMCE (Source: TU Wien, Stadtgemeinde Ebreichsdorf, Energiepark Bruck/Leitha, Energie- und Umweltagentur NÖ, 2015. Projektantrag Smart City Ebreichsdorf (SMCE). Wien: TU Wien; own presentation)

Within the work package 1 "Smart City Future-Dialog" the subject Smart City Ebreichsdorf is going to be made accessible to a wider audience and motivational processes of participation are going to be provided. For example, a short survey on the "quality profile of Ebreichsdorf" is going to be conducted as well as a visiting possibility of the warehouse tower of Ebreichsdorf ("Lagerhausturm") is going to be arranged to get a "new perspective" on the city. Furthermore, projects with young people are going to be performed in order to capture their images of their future living environment. Six think tanks with stakeholders such as the Lower Austrian government and the ÖBB are going to be held, so as to discuss issues such as land management, land mobilization and mobility. In these conversations necessary dimensions of action for planning and implementation processes of Smart City concepts should be designed. Future workshops both within the research team as well as with the citizens are going to be applied.

Work package 2 "Railway station of the future" has three topics, as they are incremental approach, holistic approach/iterative steps and integrated design. At first the basics will be prepared to develop a 
Can a new railway track be used to foster smart urban and regional development?

set of requirements, which in turn are the basis for creating the design concept. Furthermore, aspects of different disciplines will be considered and taken into account, both in the creation of the foundations as well as in further steps. Within this iterative paths are possible and necessary. An integrated design is the third topic, where planning approaches, content and concepts from different disciplines will be brought together. This requires the cooperation of all involved disciplines in terms of customized technology.

To discuss future models of district development, an open, inspiring access is being needed. Work Package 3 "Railway station district of the future" works with a scenario technique, which allows exploring alternative development paths, to raise awareness of possible developments and to clarify spatial models and objectives. Furthermore it makes possible to determine critical decisions and courses of action as well as to explain contexts for future innovation. The aim is to derive model-like and perspective oriented recommendations for action in the development of the district surrounding the station in Ebreichsdorf.

Work package 4 "Energy Town / Region" shows the possibilities of a Smart Energy City or Region on the example of a city district in Ebreichsdorf. Three priorities have been defined for this purpose. These are the development of energy-efficient and intelligent settlements and infrastructure followed by economically and ecologically optimized use of renewable energy sources and at third priority the consideration of energy-conscious lifestyles as well as proactive awareness training.

\section{Scenario technique}

Using the scenario technique the future development of Ebreichsdorf and the area surrounding the new train station is simulated. Four different scenarios were developed that bring different advantages and disadvantages for the city (see Fig. 4). At a workshop with all researchers, the four scenarios will be discussed and challenges such as energy-efficient settlement development and the potential impact of the new station to the existing town centers will be highlighted. Moreover, these scenarios will be the basis for the future workshop with the citizens.

The first scenario "Station Ebreichsdorf NEW" concentrates the future development of the city around the new station. New settlements for living and work are to build just around the station. Thereby, old town centers will be partly replaced by the new center in their meaning and function.

In contrast to this, in the second scenario "Extend the existence" there will be no development around the station and the impulsion of the new station will be concentrated in the existing centers. Postcompaction and the reduction of vacancies will be the focus. The area around the station will function as local recreation area and in prevents the convergence of Ebreichsdorf and Unterwaltersdorf. Similar to this, also the third scenario "Sharp edges" prevents new settlements around the station, but concentrates the expansion of Ebreichsdorf in the direction of the new station. Clear settlement boundaries and a recreation area around between Ebreichsdorf and Unterwaltersdorf are the consequences.

The fourth and last scenario "Building bridges" also concentrates development around the station, but also links the city districts. Thus, a new center is being built without weaken the existing centers. The barrier effect of the railroad track will be minimized. 


\section{Four scenarios}

for the "railway station district of the future ${ }^{\text {" }}$

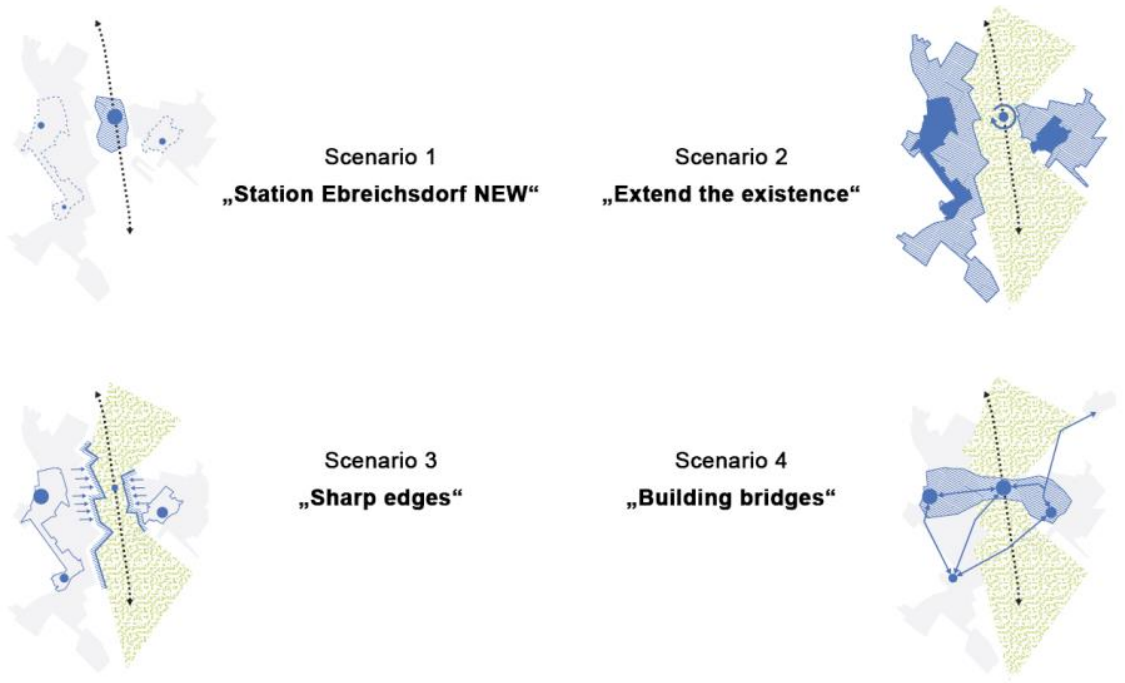

Fig. 4: Four scenarios for Ebreichsdorf (Source: (Weisböck, et al., 2016))

\section{Conclusion}

It is already evident after the first few weeks of the project that it is a good approach to have a widely diversified research team as mentioned previously. The team is working well together and in the course of the first scenario workshop, it became clear that all different disciplines have different accesses to the same topic. Through this a stimulating discussion and exchange of experiences has been started. The complex nature of Smart City applies the cooperation of different scientific disciplines such as spatial planning, architecture, civil engineering and social sciences.

The scenario technique has again made clear, that it is challenging to embed a new railway station in the existing urban structure. Due to this the advantages and disadvantages of individual development opportunities could be show.

Furthermore, the so far performed processes of participation highlight, that citizens show high interest in taking part in the process of exploring and planning the future of Ebreichsdorf. Thus, they show an open-minded attitude to discuss different scenarios. This might be due to the early stage they were informed and included in the project. 
Can a new railway track be used to foster smart urban and regional development?

Another success is, that the acceptance and the need for the project have been recognized by all political parties and that key actors like the ÖBB are included in the process.

Until February 2017 SMCE elaborates development criteria for four thematic main points: planning und processes, train station, quarter, energy and resources. They are the basis for a following execution in a concrete city development project. The research results can be used directly in the testbed Ebreichsdorf. Furthermore, some of the results may be repeatable in similar projects in Austria, but also on the international level. The gained knowledge shall cause learning processes in politics, the planning administration and the scientific community as well as a concrete realization of the Smart City Demo Projects in Ebreichsdorf.

\section{References}

1. Caragliu, A., Del Bo, C. \& Nijkamp, P., 2011. Smart Cities in Europe. Journal of Urban Technology, Vol. 18(Issue 2), pp. 65-82.

2. Dameri, R. P., 2013. Searching for Smart City definition: a comprehensive proposal. International Journal of Computers \& Technology, 11(5), pp. 2544 - 2551.

3. FFG, 2015. Programme: Smart Cities Demo. [Online] Available at: www.ffg.at/programme/smart-cities-demo [Accessed 20 May 2016].

4. Giffinger, R. \& Heindlmayer, G., 2010. Smart Cities Ranking: An effective instrument for the positioning of cities. ACE 12: Architecture, City and Environment, pp. 7-25.z

5. google maps, 2016. google.maps. [Online] Available at: www.google.at/maps/@47.9641112,16.4190001,4160m/data=!3m1!1e3 [Accessed 20 May 2016].

6. Hollands, R. G., 2008. Will the real smart city please stand up?. City, Vol. 12(No. 3), pp. 303320.

7. Nam, T. \& Pardo, T. A., 2011 a. Conceptualizing Smart City with Dimensions of Technology, People, and Institutions. The Proceedings of the 12th Annual International Conference: Digital Government Research, pp. 282 - 291.

8. Nam, T. \& Pardo, T. A., 2011 b. Smart City as Urban Innovation: Focusing on Management, Policy, and Context. ICEGOV '11 Proceedings of the 5th International Conference on Theory and Practice of Electronic Governance, pp. 185 - 194.

9. Neirotti, P. et al., 2014. Current trends in Smart City initiatives: Some stylised facts. Cities, Volume 38, pp. 25-36.

10. ÖBB Infra, 2016 a. ÖBB Infra: Südstrecke. [Online] Available at: www.oebb.at/infrastruktur/de/5_0_fuer_Generationen/5_4_Wir_bauen_fuer_Generationen/5_4_ 1_Schieneninfrastruktur/Suedstrecke/Zweigleisiger_Ausbau_der_Pottendorfer_Linie/index.jsp [Accessed 18 Mai 2016].

11. ÖBB Infra, 2016 b. Südstrecke: Südstrecke online. [Online] Available at: http://www.oebb.at/infrastruktur/de/5_0_fuer_Generationen/5_4_Wir_bauen_fuer_Generationen 
Book of Proceedings

International Conference on Architecture and Spatial Planning

15_4_1_Schieneninfrastruktur/Suedstrecke/suedstreckeonline/index.html [Accessed 20 May 2016].

12. ÖBB Infra, n.d.. Schieneninfrastruktur: Südstrecke. [Online] Available at: http://www.oebb.at/infrastruktur/de/5_0_fuer_Generationen/5_4_Wir_bauen_fuer_Generationen 15_4_1_Schieneninfrastruktur/Suedstrecke/index.jsp [Accessed 20 May 2016].

13. TU Wien, Stadtgemeinde Ebreichsdorf, Energiepark Bruck/Leitha, Energie- und Umweltagentur NÖ, 2015. Projektantrag Smart City Ebreichsdorf (SMCE). Wien: TU Wien.

14. Weisböck, M., Ziegler, R. \& Scheuvens, R., 2016. Szenarienworkshop: Smart City Ebreichsdorf - Bahnhofsquartier der Zukunft. Wien: TU Wien. 